\title{
KAPASITAS PEMERINTAHAN DESA DALAM IMPLEMENTASI UNDANG-UNDANG NOMOR 6 TAHUN 2014 TENTANG DESA DI JAWA TENGAH
}

\author{
SUHARTO \\ Dosen Ilmu Politik , Fakultas Ilmu Sosial dan Ilmu Politik \\ Universitas Wahid Hasyim Semarang \\ EMAIL: hartoss@gmail.com
}

\begin{abstract}
This article describes the Capacity of the Village Government in the framework of implementing the 2014 Law Number 6 concerning Villages which is very important in determining its success. In this study aims to determine the extent of the capacity of the Village Government in implementing the Village Law. Looking at the current condition of the Village which is very heterogeneous, both quantity, quality or capacity and even the potential of natural resources and human resources are very varied, so in the context of implementing the Village Law it needs to be addressed or concern us, especially academics. The problems in this study are: "What is the capacity of the village government in the framework of implementing the Law Number 6 of 2014 concerning Villages?. Looking at the present condition of the village nationally, special steps are needed in the framework of implementing the Village Law. The parallel steps that must be considered and carried out in order to succeed the implementation of the Village Law include: First, the capacity level of the Village Government, namely the readiness of the Village Tools and Village Institutions (quantity and quality). Quantitatively, most villages currently do not have complete equipment as stipulated in PP 43/2014 article 61-article 64. Meanwhile, the available equipment capacity still needs to be improved. Second, the quality of the compilation of Village Development Planning documents (Village RPJM, Village RKP and Village APB). Based on PP 43/2014, paragraphs 114-115 and PP 60/2014 ps. 20, it is stated that the use of the Village Fund refers to the Village Medium Term Plan (RKPDes) and Village Government Work Plan (RKPDes). The implementation of the Village Law requires the capacity of the village government to master the technical and mechanism of managing trained and professional finance. With a number of issues, the current unprepared capacity makes feedback in efforts to improve the capacity of village financial management, together with all stakeholders (stakeholders), actors in the field, groups of care / volunteers and all village communities, because village funds must be able to promote the village and prosper villagers.
\end{abstract}

Keywords: Village Government Capacity, Implementation of Village Law 


\section{A. LATAR BELAKANG MASALAH}

Undang-Undang Nomor 6 Tahun 2014 tentang Desa tidak hanya membawa sumber pendanaan pembangunan bagi desa, namun juga memberi lensa baru pada masyarakat untuk mentransformasi wajah desa. UU Desa lebih pada pendekatan pemberdayaan masyarakat yang memposisikan masyarakat desa sebagai subyek (pelaku utama) dan tidak hanya sekedar obyek (sasaran) saja. Melalui pemberdayaan masyarakat Desa diharapkan mampu membawa perubahan nyata sehingga harkat dan martabat mereka pulih kembali.

Melihat realitas kondisi desa saat ini yang sangat heterogen sekali baik kuantitas, kualitas atau kapasitas Pemerintahan Desa dan bahkan potensi SDA dan SDM nya sangat bervariatif dalam rangka implementasi UU Desa ini, maka perlu adanya perhatian kepada Desa tentang kelembagaan Desa, SDM dan SDA nya untuk mensikapi diberlakukannya UU tersebut Untuk itu diperlukan sebuah penelitian untuk mengetahui sejauh mana tinggkat kapasitas Pemeintahan Desa dalam implementasi UU Nomer 6 Tahun 2014 tentang Desa.

\section{B. PERMASALAHAN}

Adapun permasalahan yang diteliti adalah : Bagaimana kapasitas Pemerintah Desa dalam rangka implementasi Undang-Undang No. 6 Tahun 2014 tentang Desa di Jawa Tengah ?

\section{TUJUAN}

Penelitian ini bertujuan : Untuk mengetahui kapasitas Pemerintah Desa dalam rangka implementasi Undang-Undang Nomer 6 Tahun 2014 tentang Desa di Jawa Tengah.

\section{URGENSI (KEUTAMAAN) PENELITIAN}

Melihat kondisi desa yang ada sekarang secara nasional masih perlu ada persiapan ataupun prakondisi dalam rangka implementasi UU Desa. Adapun langkah-langkah paralel yang harus dilakukan dalam rangka implementasi UU Desa terkait peningkatan kapasitasnya antara lain adalah : Pertama, Penyiapan Perangkat Desa dan Kelembagaan Desa (Kuantitas dan kualitas). Secara kuantitas sebagian besar desa saat ini tidak memiliki perangkat yang lengkap sebagaimana diatur dalam PP 43 /2014 pasal 61-pasal 64. Sementara itu perangkat yang tersedia kapasitasnya masih perlu ditingkatkan. Belum ada pelatihan-pelatihan khusus dan sistematis yang diberikan kepada perangkat desa maupun kelembagaan desa (BPD dll) terkait pelaksanaan (implementasi) UU Desa. 
Kedua, Penyiapan Perencanaan Pembangunan Desa (RPJM Desa, RKP Desa dan APB Desa). Berdasarkan PP 43 /2014 psl 114-115 dan PP 60 /2014 psl 20 disebutkan penggunaan Dana Desa mengacu pada Rencana Jangka Menengah Desa (RKPDes) dan Rencana Kerja Pemerintah Desa (RKPDes). Saat ini hanya terdapat kurang lebih 53.000 desa yang memiliki dokumen RPJMDes yang telah difasilitasi PNPM Mandiri Perdesaan. Sebagian besar belum memiliki APB Desa dan RKP Desa yang masihperl difasilitasi kapasitasnya dalam mewujudkannya .

\section{E. KAJIAN PUSTAKA}

Menurut Woll (1966) mengartikan kebijakan publik adalah “ sejumlah aktivitas pemerintah untuk memecahkan masalah dimasyarakat, baik secara langsung maupun melalui berbagai lembaga yang mempengaruhi kehidupan masyarakat. Konsep kebijakan publik yang diberikan oleh Anderson (1979 : 46), yaitu "Public Policies are those policies developed by governmental bodies and officials". ("Kebijakan publik adalah kebijakan-kebijakan yang dikembangkan oleh badan-badan dan pejabat-pejabat pemerintah").

Jadi kebijakan publik timbul melalui serangkaian proses. Artinya, kebijakan publik tidak timbul secara mendadak, melainkan melalui suatu proses tertentu yang berkaitan dengan tujuan-tujuan kebijakan. Proses yang dilalui oleh kebijakan publik merupakan suatu rangkaian yang saling berkaitan, yang setiap tahap dalam rangkaian prosesnya akan mempengaruhi tahap-tahap lainnya. Proses kebijakan publik melewati empat rangkaian tahap tindakan pemerintah.

1. Pertama, tahap persepsi/definisi agregasi, organisasi, representasi, dan penyusunan agenda, yang merupakan tindakan membawa permasalahan pada pemerintah.

2. Kedua, tahap formulasi, legitimasi, dan penganggaran, yang pada dasarnya merupakan suatu tindakan langsung pemerintah untuk mengembangkan dan mendanakan sebuah program.

3. Ketiga, tahap implementasi atau pelaksanaan, adalah sebagai tindakan pemerintah untuk kembali pada permasalahan.

4. Keempat, tahap evaluasi dan penyesuaian/ terminasi, yang pada dasarnya adalah kembalinya program kepada pemerintah untuk dilakukan peninjauan kembali atau perubahan-perubahan bilamana diperlukan. 


\section{Bagan : Tahapan Kebijakan Publik dalam Good Governance}

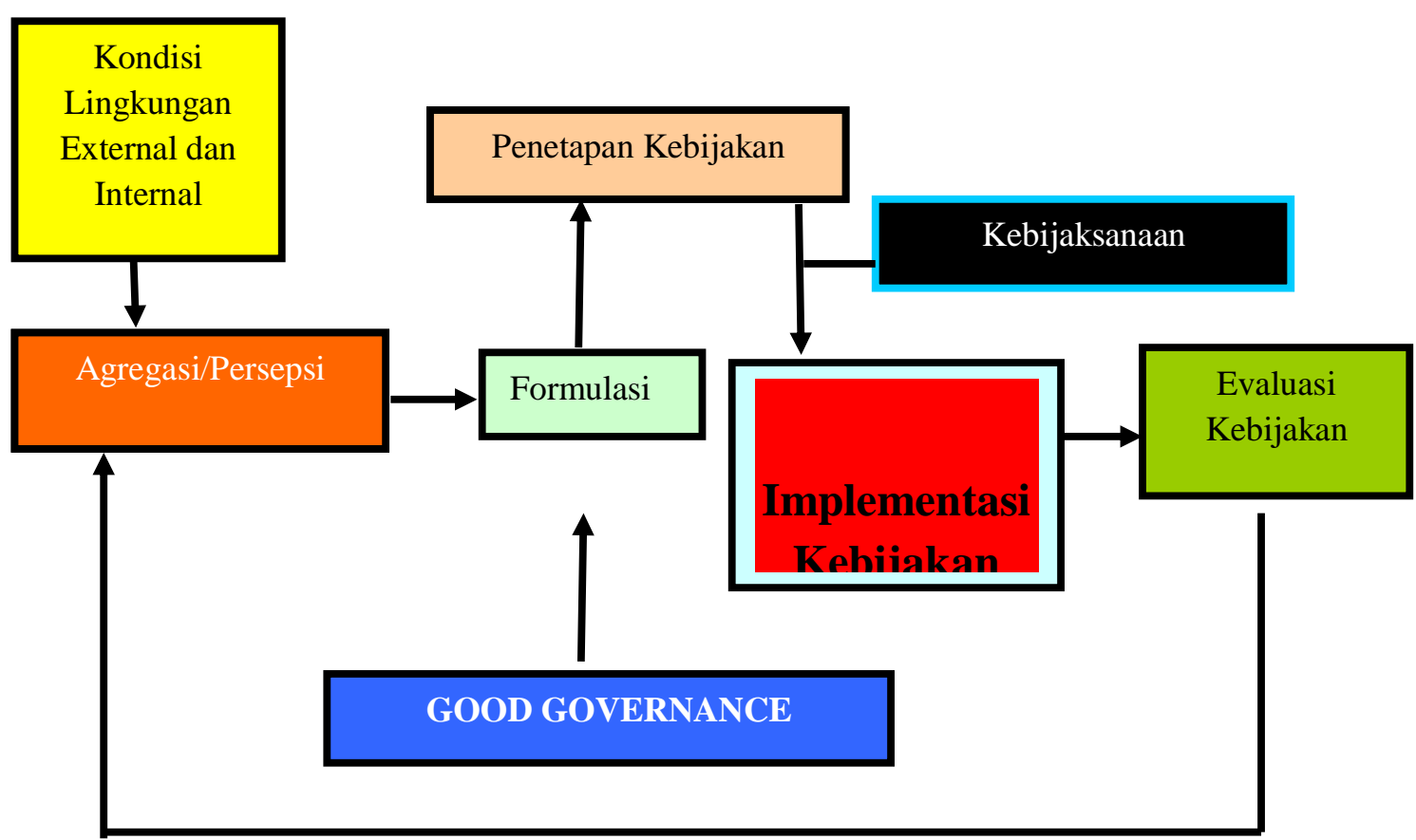

Makna dan hakekat kebijakan publik merupakan suatu keputusan yang dilaksanakan oleh Pejabat Pemerintah yang berwenang untuk kepentingan masyarakat (public interest). Kepentingan masyarakat ini merupakan keseluruhan yang utuh dari perpaduan dan kristalisasi pendapat-pendapat, keinginan-keinginan dan tuntutan-tuntutan (demands) dari rakyat. Edward dan Sharansky dalam Wahab (1997 : mengutarakan bahwa: "kebijakan public itu dapat ditetapkan secara jelas dalam peraturan-peraturan, perundang-undangan atau dalam bentuk pidato-pidato pejabat teras pemerintah ataupun berupa program-program dan tindakan-tindakan yang dilakukan pemerintah. Sedangkan dalam kehidupan masyarakat bernegara saat ini, baik individu, berkelompok maupun masyarakat sangat dipengaruhi oleh negara. Pengaruh ini dapat dicermati atau dirasakanmulai seseorang dilahirkan sampai mati dalam berbagai bentuk pengaturan dan kontrol Pemerintah yang bertindak atas nama negara. Fenomena ini merupakan perwujudan diterimanya welfare state. Oleh sebab itu intervensi negara akan memberikan bentuk beragam dari pelayanan publik yang dilakukan Pemerintah.

Dengan melihat teori atau konsep kebijakan publik yang telah diuraikan tersebut maka UU Nomer 6 Tahun 2014 tentang Desa merupakan out put kebijakan publik. Dan sekarang ini harus dimulai tahapan selanjutnya yaitu implementasi dari kebijakan tersebut. Untuk memulai (memberlakukan) UU Desa perlu mengetahui kapasitas pemerintahan desa terkini, karena UU 
Desa ini bisa berjalan dengan baik dan efektif manakala ada kemampuan dari pemerintahan desa dan didukung masyarakatnya..

Dalam kaitan kapasitas Pemerintahan Desa, dalam hal perencanaan desa, kewenangan-kewenangan ideal untuk Desa yaitu antara lain :

1. kewenangan untuk terlibat dalam proses perumusan kebijakan pemerintah daerah yang mengatur tentang desa,

2. kewenangan untuk menentukan kebijakan yang berkaitan dengan urusan-urusan internal desa,

3. kewenangan untuk mengelola dana perimbangan yang berasal dari DAU,

4. kewenangan untuk mengelola sumber daya ekonomi yang berada di tingkat desa,

5. kewenangan untuk menolak program-program tugas pembantuan pemerintah di atasnya yang tidak disertai dengan pembiayaan, sarana, prasarana, dan tidak sesuai dengan daya dukung desa dan kehendak masyarakat setempat.

Kemampuan desa dalam menggunakan kewenangan-kewenangan yang disebutkan ini menunjukkan kemampuan/ kapasitas desa dalam melaksanakan otonomi desa. Masih ada sejumlah sisi lemah kapasitas pemerintahan desa mencakup:

a. lemahnya konsolidasi internal pemerintah desa,

b. lemahnya responsibilitas dan kompetensi personil perangkat desa,

c. masih kuat dan dominasinya kepemimpinan kepala desa,

d. tradisi administrasi modern yang masih minim,

e. kurangnya kemampuan dalam mengelola keuangan desa,

f. kurangnya kemampuan dalam menggali potensi desa,

g. lemahnya responsifitas pemerintah desa terhadap kebutuhan masyarakat,

h. kurangnya kemampuan merumuskan peraturan desa,

i. kurangnya kemampuan melakukan inovasi terhadap pemerintah, pelayanan dan pembangunan desa, 
j. lemahnya partisipasi masyarakat desa (Sutro Eko, dalam Djaha, 2007).

Pengembangan Kapasitas (Capacity Building) dapat dicermati sebagai berikut : Morison (Riyadi, 2005) melihat pengembangan kapasitas sebagai suatu proses untuk melakukan sesuatu, atau serangkaian gerakan, perubahan multi level di dalam individu, kelompok-kelompok, organisasi-organisasi dan sistem-sistem dalam rangka untuk memperkuat kemampuan penyesuaian individu dan organisasi sehingga dapat tanggap terhadap perubahan lingkungan yang ada. Katty Sensions (Riyadi, 2005) menyatakan capacity building umumnya dipahami sebagai upaya membantu pemerintah, masyarakat ataupun individu dalam mengembangkan keahlian dan ketrampilan yang dibutuhkan untuk mewujudkan tujuan-tujuan mereka. Program pengembangan kapasitas seringkali didesain untuk memperkuat kemampuan dalam mengevaluasi pilihan-pilihan kebijakan mereka dan menjalankan keputusan-keputusannya secara efektif. Pengembangan kapasitas bisa meliputi pendidikan dan pelatihan, reformasi peraturan dan kelembagaan, dan juga asistensi finansial, teknologi dan keilmuwan

Pengembangan kapasitas Pemerintah Desa diarahkan pada peningkatan kemampuan (baik secara kelembagaan maupun personal aparatur) dalam mengelola atau menjalankan fungsi pemerintahan, pembangunan da pelayanan masyarakat di desa untuk mencapai tujuan penyelenggaraan pemerintahan desa. United Nations memberi rujukan Capacity Building yang berdimensikan pada; 1) Mandat dan struktur legal, 2) Struktur kelembagaan, 3) Pendekatan manajerial, 4) Kemampuan organisasional dan teknis, 4) Kemampuan fiskal lokal, dan 5) Aktivitas-aktivitas program.

World Bank menekankan perhatian capacity building pada ;

a. Pengembangan sumber daya manusia; training, rekruitmen dan pemutusan pegawai profesional, manajerial dan teknis,

b. Keorganisasian, yaitu pengaturan struktur, proses, sumber daya dan gaya manajemen,

c. Jaringan kerja (network), berupa koordinasi, aktifitas organisasi, fungsi network, serta interaksi formal dan informal,

d. Lingkungan organisasi, yaitu aturan (rule) dan undang-undang (legislation) yang mengatur pelayanan publik, tanggung jawab dan kekuasaan antara lembaga, 
kebijakan yang menjadi hambatan bagi development tasks, serta dukungan keuangan dan anggaran.

e. Lingkungan kegiatan lebih luas lainnya, meliputi faktor-faktor politik, ekonomi dan situasi-kondisi yang mempengaruhi kinerja.

Beberapa dimensi capacity building bagi Pemerintahan Desa antara lain :

a. pengembangan sumber daya manusia,

b. penguatan organisasi dan manajemen,

c. penyediaan sumber daya, sarana dan prasarana,

d. network (pengembangan jaringan atau kerjasama),

e. lingkungan; dan mandat, kemampuan fiskal, dan program.

Terdapat banyak faktor yang mempengaruhi penyelenggaraan maupun kesuksesan program pengembangan kapasitas dalam pemerintahan daerah. Namun secara khusus dapat disampaikan bahwa dalam konteks pembangunan daerah / kawasan ataupn pemerintahan desa, faktor-faktor signifikan yang mempengaruhi pembangunan kapasitas meliputi 5 (lima) hal pokok yaitu komitmen bersama, kepemimpinan, reformasi peraturan, reformasi kelembagaan, dan pengakuan tentang kekuatan dan kelemahan yang dimiliki daerah / kawasan.

\section{F. METODE PENELITIAN}

Instrumen penelitian ini yang dipakai adalah metode dokumentasi. Di dalam melaksanakan metode dokumentasi, peneliti menyelidiki benda-benda tertulis seperti buku-buku / liteatur, majalah, dokumen, peraturan-peraturan, notulen rapat, dan sebagainya. Dalam penelitian literatur, maka teknik pengumpulan data menggunakan teknik library reseach (penelitian pustaka), yaitu dengan mengambil data dari buku-buku, artikel, dan website/internet. Metode yang digunakan dalam penelitian ini adalah metode penelitian deskriptif-kualitatif, yaitu berusaha menguraikan, menjelaskan penyebab suatu masalah berdasarkan data dan fakta yang ada. Dalam penelitian ini analisis datanya diperoleh melalui interpretasi dokumentasi yang terkumpul, kemudian dianalisis secara deskriptif-kualitatif, yaitu mendeskripsikan suatu situasi atau area populasi tertentu bersifat faktual secara sistematis dan akurat. 


\section{G. KAPASITAS PEMERINTAHAN DESA DALAM IMPLEMENTASI}

UNDANG-UNDANG NOMOR 6 TAHUN 2014 TENTANG DESA DI JAWA TENGAH

\section{a. Gambaran Umum Implementasi Undang-Undang Nomor 6 Tahun 2014} Tentang Desa Di Jawa Tengah.

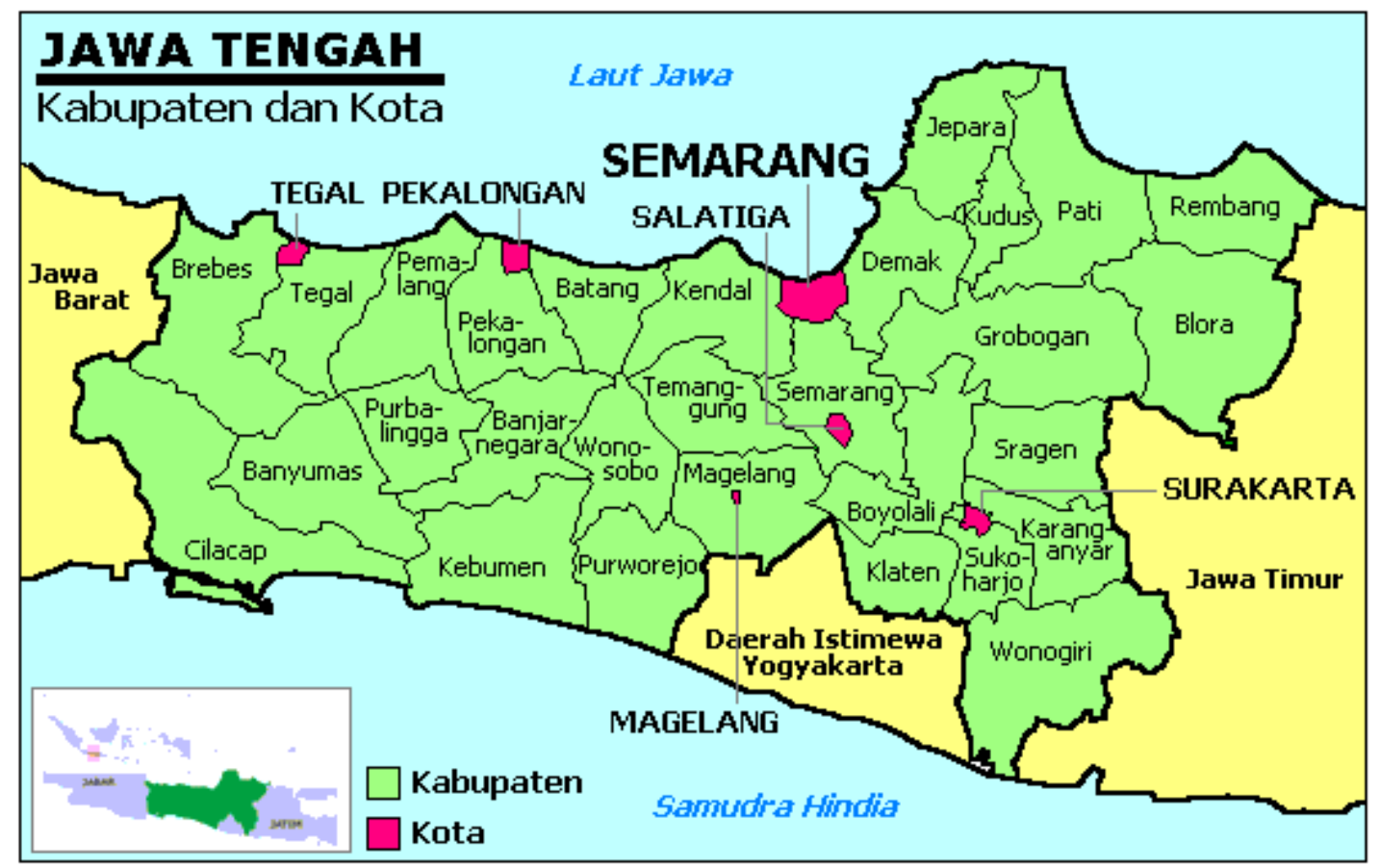

PETA PROVINSI JAWA TENGAH

(Sumberhttp://www.kopi-ireng.com/2016/11/peta-jawa-tengah-lengkap-besertakabupaten-dan-kota.html)

Jawa Tengah adalah sebuah provinsi Indonesia yang terletak di bagian tengah Pulau Jawa. Ibu kotanya adalah Semarang. Provinsi ini berbatasan dengan Provinsi Jawa Barat di sebelah barat, Samudra Hindia dan Daerah Istimewa Yogyakarta di sebelah selatan, Jawa Timur di sebelah timur, dan Laut Jawa di sebelah utara. Luas wilayahnya $32.548 \mathrm{~km}^{2}$, atau sekitar 28,94\% dari luas pulau Jawa. Provinsi Jawa Tengah juga meliputi Pulau Nusakambangan di sebelah selatan (dekat dengan perbatasan Jawa Barat), serta Kepulauan Karimun Jawa di Laut Jawa. 
Pengertian Jawa Tengah secara geografis dan budaya kadang juga mencakup wilayah Daerah Istimewa Yogyakarta. Jawa Tengah dikenal sebagai "jantung" budaya Jawa. Meskipun demikian di provinsi ini ada pula suku bangsa lain yang memiliki budaya yang berbeda dengan suku Jawa seperti suku Sunda di daerah perbatasan dengan Jawa Barat. Selain ada pula warga Tionghoa-Indonesia, Arab-Indonesia dan India-Indonesia yang tersebar di seluruh provinsi ini.

Secara administratif, Provinsi Jawa Tengah terdiri atas 29 kabupaten dan 6 kota. Administrasi pemerintahan kabupaten dan kota ini terdiri atas 545 kecamatan dan 8.490 desa/kelurahan. Sebelum diberlakukannya Undang-undang Nomor 22/1999 tentang Pemerintahan Daerah, Jawa Tengah juga terdiri atas 3 kota administratif, yaitu Kota Purwokerto, Kota Cilacap, dan Kota Klaten. Namun sejak diberlakukannya Otonomi Daerah tahun 2001 kota-kota administratif tersebut dihapus dan menjadi bagian dalam wilayah kabupaten. Menyusul otonomi daerah, 3 kabupaten memindahkan pusat pemerintahan ke wilayahnya sendiri, yaitu Kabupaten Magelang (dari Kota Magelang ke Mungkid), Kabupaten Tegal (dari Kota Tegal ke Slawi), serta Kabupaten Pekalongan (dari Kota Pekalongan ke Kajen).

Pada tahun 2017 Provinsi Jawa Tengah mendapat alokasi Dana Desa sebesar Rp.6.384.442.058.000,- lebih besar dari tahun sebelumnya 2016 yaitu Rp.5.002.426.341.000,- atau naik Rp.1.382.015.717.000,- (27,63\%) untuk 7.809 desa di 29 Kabupaten . Besaran dana desa perdesa \pm Rp. 800.000.000,- penetapananggaran per desa di dukung dengan diterbitkanya regulasi / perda Kabupaten masing - masing yang mengatur tentang ketentuan dan penggunaannya Dana desa tersebut.

Implementasi Undang-Undang Nomor 6 Tahun 2014 tentang Desa telah diberlakukan, jika dibandingkan dengan kebijakan-kebijakan sebelumnya bahwa desa tidaklah sekedar pemerintahan desa, namun desa sebagai suatu kesatuan sosial-budaya, ekonomi, dan juga politik dan hukum. Maka, kebijakan dan regulasi tentang desa ke depan harus lebih dari sekedar pemerintahan desa itu. Kebijakan dimaksud haruslah mengarah pada realisasi pengakuan atas hak asal-usul yang melihat desa baik sebagai persekutuan sosial dan budaya; desa sebagai persekutuan hukum, politik, dan pemerintahan; dan desa sebagai persekutuan ekonomi (sebagai ekspresi dari penguasaan desa atas sumber-sumber kehidupan yang menjadi ulayatnya. 
Dengan pemikiran yang demikian itu maka dalam merevitalisasi desa sebagai modal sosial dalam menyongsong masa depan yang tidak mudah . hal ini karena faktor-faktor lokal, nasional, dan global. Selain itu, kebijakan baru dimaksudkan juga untuk mengkonsolidasi kembali sistem hak-hak masyarakat adat melalui pengakuan hak-hak asal desa sebagai dasar bagi 'pembaruan desa' dengan 'reforma agraria', sebagaimana telah diamanatkan dalam TAP MPR IX/2001.

Namun semenjak diundangkan 3 tahun lalu, UU Desa menjadi arena pertaruhan gagasan dalam implementasinya. Apa sesungguhnya yang sudah terjadi dalam 3 tahun implementasi UU Desa itu yang perlu kita ketahui bersama. Tampaknya, tidak mudah untuk menarik kesimpulan yang paripurna. Tidak adanya data awal yang digunakan sebagai pedoman dalam melaksanakan UU Desa. Hal itu telah menyulitkan para pihak untuk mengevaluasi capaian implementasi UU Desa dalam 3 tahun terakhir. Sehingga capaian Provinsi Jawa Tengah dalam lebih banyak menyelesaikan pendataan ini agar ke depan menjadi bahan pijakan melakukan evaluasi.

Keluhan bahwa UU Desa dilaksanakan setengah hati oleh Pemerintah, sehingga masyarakat belum merasakan manfaat dari adanya UU Desa, juga menjadi keluhan umum berikutnya. Pemerintah, mulai dari Pusat hingga kabupaten, belum bisa menangkap roh UU Desa. Prinsip rekognisi dan subsidiaritas selama ini kurang ditaati Pemerintah, ini salah satu temuan seorang Pendamping Desa di Jawa Tengah.

Setelah menjalankan UU Desa dalam berbagai proses kegiatannya di Jawa Tengah, dapat di mapping permasalahannya, setidaknya dapat dirinci 3 pokok masalah yang masih dihadapi UU Desa di tingkat lapangan antara lain :

Pertama, soal perencanaan pembangunan desa. Tidak semua desa melakukan proses konsultasi dengan warga. Keterlibatan dan akses warga atas perencanaan desa amat terbatas.

Kedua, transparansi alokasi penggunaan dana desa dan pengelolaan BUMDes. Biasanya hanya elit desa saya yg membicarakannya. Warga atau perwakilan warga tidak diberi info yang cukup dan terbuka soal rencana pendirian BUMDes ini.

Ketiga, kepemimpinan desa sangat menentukan apakah sebuah desa akan cukup inovatif mengelola kekayaan desa (dalam arti luas, misalnya dalam 
kerangka sustainable livilihood: aset keuangan, aset natural, aset sumberdaya manusia, aset sosial, aset fisik).

Dengan kondisi dan situasi diapangan yang secaa riil tersebut, maka yang terjadi adalah pelaksanaan/ implementasi UU Desa masih belum bisa optimal dan masih berparadigma "pembangunan di desa" bukan "pembangunan desa". BUMDes dianggap mirip BUMD dan bukan milik desa. Musyawarah desa juga belum berjalan optimal. Yang sudah berjalan selama ini baru musyawarah pembangunan desa (musrenbangdes).

Seperti biasanya, hasilnya selalu seperti yang telah diarahkan oleh Bappeda Kabupaten. Mengutip survei yang dilakukan TAPD atas berita media massa. Dengan mengecualikan beberapa kunci yang secara apriori sudah dapat dipastikan sangat dominan, yaitu 'undang-undang desa' dan 'dana desa', hasil yang menonjol, jika diurut dari yang tertinggi hingga yang terendah, adalah sebagai berikut. (1) 'Pilkades' (Pemilihan Kepala Desa); (2) 'BUMDes' (Badan Usaha Milik Desa); (3) RPJMDes (Rencana Pembangunan Janka Menengah Desa); (4) 'Musdes' (Musyawarah Desa); dan (5) APBDes (Anggaran Pendapatan dan Belanja Desa). Dengan kata lain, dua kepentingan kelompok elit desa, jika dapat dikatakan begitu, jauh mendapatkan tempat ketimbang 3 urusan yang terkait kepentingan warga desa pada umumnya. Itulah faktanya. Setiap pihak memiliki kepedulian yang berbeda jika dibandingkan dengan kepedulian pihak lainnya.

\section{b. Kapasitas Pemerintahan Desa Dalam Implementasi Undang-Undang Desa.}

Musyawarah Perencanaan Pembangunan (Musrenbang) desa adalah forum musyawarah tahunan para pemangku kepentingan (stakeholders) desa untuk menyepakati Rencana Kerja Pembangunan Desa (RKP Desa) tahun anggaran yang akan direncanakan. Musrenbang desa dilakukan setiap bulan Januari dengan mengacu kepada dokumen Rencana Pembangunan Jangka Menengah Desa (RPJM Desa). Setiap desa diamanatkan untuk menyusun dokumen rencana 5 tahunan yaitu RPJM Desa dan dokumen rencana tahunan yaitu RKP Desa. Musrenbang adalah forum perencanaan program yang diselenggarakan oleh lembaga publik, yaitu pemerintah desa, bekerjasama dengan warga dan para pemangku kepentingan lainnya. Musrenbang yang bermakna akan mampu membangun kesepahaman tentang kepentingan dan kemajuan desa, dengan cara memotret potensi dan sumber-sumber pembangunan yang tersedia baik dari dalam maupun luar desa. 
Sejak disahkan pada tahun tiga tahun silam, UU No 6 Tahun 2014 tentang desa menjadi salah peraturan perundang-undangan tersubur dengan menghasilkan 2 Peraturan Pemerintah (PP) dan 3 Peraturan Presiden (Perpres) sebagai turunannya. Meski demikian, dalam implementasinya, UU ini masih mengalami berbagai kendala, khususnya dalam pengelolaan dana desa. Berkaitan dengan pengelolaan dana desa, ada beberapa aspek penting yang menjadi perhatian dalam implementasi UU desa, yaitu tata kelola desa, pengelolaan dana desa, serta peningkatan kapasitas masyarakat. Untuk dapat berhasil dalam ketiga aspek tersebut, perlu ada perhatian terhadap implementasi UU Desa sejak dalam proses formulasi hingga implementasinya. Dari aspek formulasi, kami menjumpai dan banyak mendengar kritik terkait besaran dana desa yang sama besar di tiap wilayah.

Sementara itu, dari aspek implementasinya, pengelolaan dana desa yang melibatkan tiga kementerian yang berbeda menimbulkan adanya tumpang tindih dalam pelaksanaan fungsi dari masing-masing pihak. Formulasi banyak dikritik karena tidak mempunyai kontribusi yang signifikan untuk mengurangi kemiskinan karena hanya dibagi rata tanpa melihat jumlah penduduk. Terlepas dari berbagai permasalahan yang ada, perlu tetap meyakini bahwa dana desa dapat menjadi solusi bagi pembangunan kawasan pedesaan. Karena itu kami berharap agar diskusi serta kajian-kajian yang dilakukan oleh para akademisi dapat menjadi rujukan bagi pemerintah untuk menjalankan kebijakan pembangunan desa.

Terkait persoalan yang dihadapi dalam pelaksanaan UU desa dan pengelolaan dana desa, aspek pengawasan sebagai hal yang krusial untuk menjamin efektivitas pemanfaatan dana desa yang sepenuhnya ditujukan bagi kepentingan masyarakat. Perlu ada gerakan masyarakat untuk dapat bersama-sama mengawal pelaksanaan UU ini. Komitmen pemerintah untuk mengurangi kesenjangan dengan menggelontorkan banyak dana adalah berita baik, tapi juga bisa jadi berita buruk jika kucuran dana yang besar ini tidak dikawal dengan baik. PR kita hari ini bagaimana mengawal dana desa yang besar ini untuk sampai kepada tujuannya secara tepat untuk kemanfaatan pembangunan pedesaan.

Implementasi UU Desa yang menjadi pokok fokus pada implementasi dana desa, adapun penyerapan dana desa di Jawa Tengah (per Oktober 2017) dapat dilihat dalam grafik dibawah ini : 


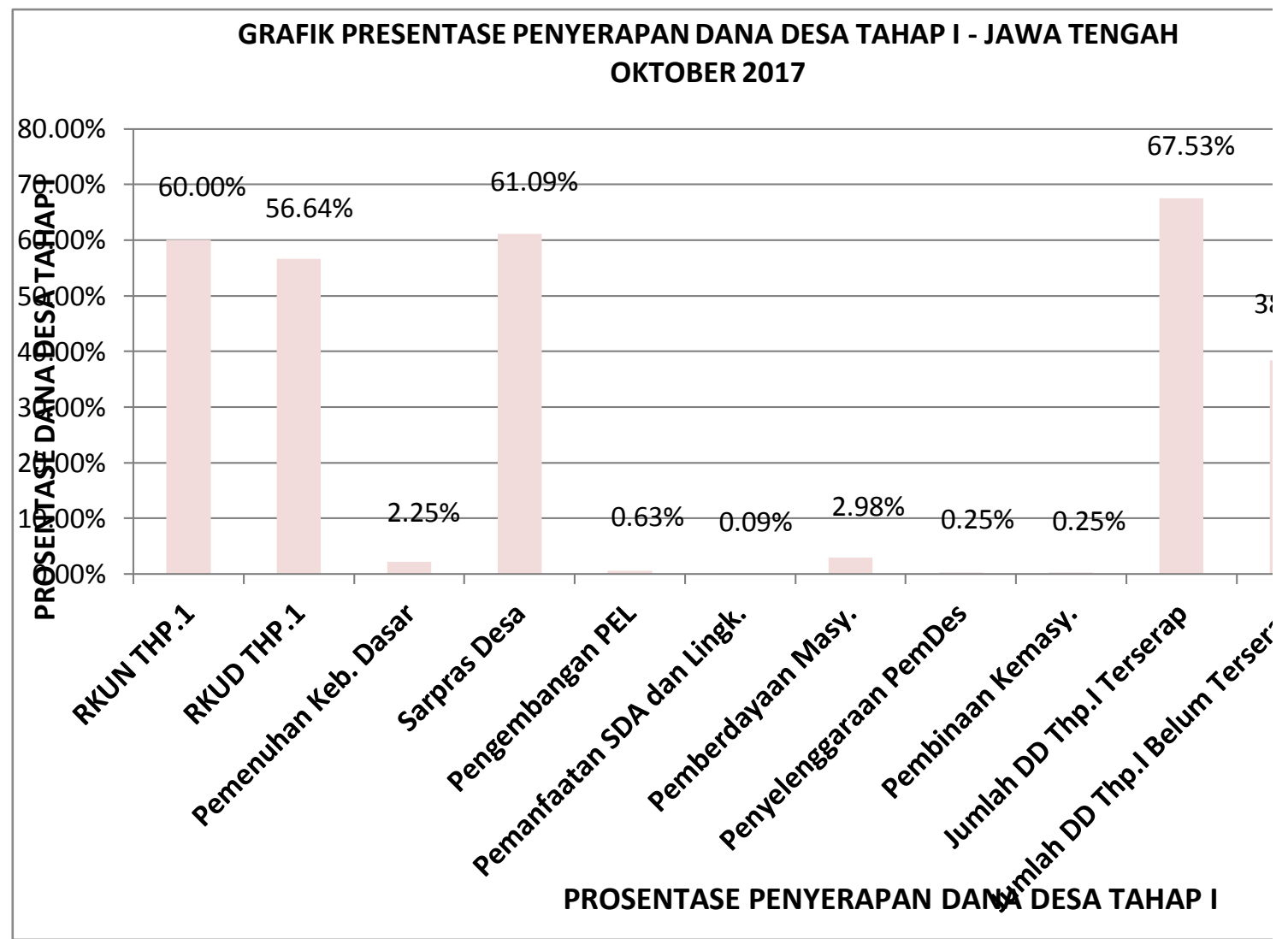

(Sumber data KPW 4 Jateng, 2017)

Walaupun penyerapannya relatif tinggi di Provinisi Jawa Tengah, namun ada beberapa potensi persoalan dalam implementasi Dana Desa ini. Yaitu terdiri dari aspek regulasi kelembagaan, aspek tata laksana, aspek pengawasan dan aspek sumber daya manusia.

a) Aspek regulasi kelembagaan terdiri dari:

1. Belum lengkapnya regulasi dan petunjuk teknis pelaksanaan keuangan desa 
2. Potensi tumpang tindih kewenangan Kemendes PDT dengan Ditjen Bina Pemerintah Desa Kemendagri,

3. Tidak transparannya formula pembagian dana desa dalam Peraturan Pemerintah (PP) Nomor 22 tahun 2015 dan hanya didasarkan atas dasar pemerataan.

4. Pengaturan pembagian penghasilan tetap bagi perangkat desa dari anggaran dana desa (ADD) yang diatur dalam PP Nomor 43 tahun 2014 dinilai kurang berkeadilan

5. Kewajiban penyusunan laporan pertanggungjawaban oleh desa yang tidak efisien akibat ketentuan regulasi dan tumpang tindih.

6. Formula pembagian dana desa yang berubah. Sebagai ilustrasi, sesuai formula PP No. 60/2014, Desa A dengan luas 7,5 km persegi dan memiliki 21 dusun akan mendapat dana desa Rp437 juta, sedangkan Desa B dengan luas Rp1,5 km dan memiliki 3 dusun maka mendapat dana Rp 41 juta. Namun dengan peraturan baru PP No. 22/2015 Desa A dapat Rp312 juta dan B Rp263 juta.

b) Ada 5 (lima) persoalan yang ditemukan dari segi pelaksanaan yaitu:

1. Kerangka waktu siklus pengelolaan anggaran desa sulit dipatuhi oleh desa,

2. Belum tersedianya atuan harga baku barang atau jasa yang dijadikan acuan bagi desa dalam menyusun APBDesa,

3. Masih rendanhnya transparansi rencana penggunaan dan pertanggungjawaban APBDesa.

4. Laporan pertanggung jawaban yang dibuat desa belum mengikuti standar dan rawan manipulasi

5. APBDesa yang disusun tidak sepenuhnya menggambarkan kebutuhan yang diperlukan desa. Temuan lapangan menunjukkan ada desa yang minim infrastruktur dan proporsi jumlah penduduk mayoritas miskin, justru memprioritaskan penggunana APBDesa untuk renovasi kantor desa yang kondisinya masih relatif baik.

c) Sedangkan pada aspek pengawasan terdapat 3 (tiga) potensi persoalan yang dihadapi, yakni:

1. Masih rendahnya efektivitas inspektorat daerah dalam melakukan pengawasan terhadap pengelolaan keuangan di desa, 
2. Tidak terkelolanya dengan baik saluran pengaduan masyarakat oleh semua daerah ,

3. Belum jelasnya ruang lingkup evaluasi dari pengawasan yang dilakukan oleh Camat.

d) Sementara dilihat dari aspek sumber daya manusia terdapat potensi persoalan yakni tenaga pendamping berpotensi melakukan korupsi dengan memanfaatkan peluang lemahnya kapasitas pemeintahan desa dan aparat desa.

Dengan sejumlah persoalan itu menjadikan umpan balik dalam upaya perbaikan pengelolaan keuangan desa bersama semua pemangku kepentingan (stakeholders), pelaku dilapangan, kelompok peduli/ relawan dan semua masyarakat desa, kaena dana desa haruslah mampu memajukan desa dan mensejahterakan masyarakat desa.

Terkait pengelolaan keuangan desa memang diperlukan kapasitas pemeintahan desa dalam teknis dan mekanisme mengelola keangan yang terlatih dan profesinal. Adapn hal-hal yang terkait pengelolaan keuangan ini yang perl diperhatikan pemerintahan desa antara lain :

1. Menetapkan standar minimum pelayanan yang berlaku seluruh daerah dalam penetapan penyusunan APBDes disetiap desa.

2. Pemerintah pusat harus berpendirian pada prinsip mempermudah penyaluran maupun pencairan dana desa dengan konsistensi dalam penerapan peraturan pemerintah sehingga tidak menyulitkan pemerintah daerah maupun pemerintah desa dalam memenuhi persyaratan-persyaratan yang ditetapkan.

3. Melalukan pendampingan kepada desa yang masih memiliki potensi yang belum mampu melakukan penyusunan APBDes dengan baik dan benar. Pendampingan tersebut dapat dilakukan oleh elemen pemerintah baik pemerintah pusat maupun pemeintah daerah dan perguruan tinggi serta NGO yang capable.

4. laporan pengelolaan harus sederhana agar dapat dimengerti oleh para perangkat desa namun tetap memenuhi prinsip transparansi dan akuntabilitas.

5. proses penyusunannya perlu dilakukan secara partisipatif dengan memberikan ruang kepada seluruh pemangku kepentingan untuk memberikan masukan.

6. Badan Permusyawaratan Desa (BPD) yang berisi wakil masyarakat desa harus berperan aktif melakukan pengawasan dan mendorong masyarakat untuk ikut mengawasi pengelolaan dana desa 
7. Untuk memperjelas batasan korupsi dana desa, Kemendagri, Kemendesa PDTT, Kemenkeu, BPKP, kepolisian, kejaksaan, dan KPK bersama-sama mengharmoniskan aturan korupsi desa. Setidaknya terkait hal-hal sebagai berikut: indikator dan jenis korupsi desa, tata cara pelaporan dan perlindungan saksi, proses pencegahan dan pembuktian korupsi, dan sanksi bagi kepala desa, perangkat desa, serta anggota BPD.

Untuk mewujudkan kapasitas pemerintahan desa dan masyarakat desa yang mandiri, pemerintah pusat melalui UU Desa mendorong setiap desa untuk mendirikan BUM Desa. Keberadaan BUM Desa diyakini akan membawa perubahan di bidang ekonomi dan sosial. Bahwa BUM Desa harus di-create agar mampu menggali potensi optimalisasi aset atau sumber daya alam desa. Situasi BUMDES di Jawa Tengah per-September 2017 adalah sebagai berikut: (Sumber data KPW 4 Jateng, 2017)

\begin{tabular}{|c|c|c|c|c|}
\hline \multicolumn{5}{|c|}{ KETERANGAN USAHA BUMDES : } \\
\hline $\begin{array}{c}\text { JASA } \\
\text { KEUANGAN }\end{array}$ & $\begin{array}{c}\text { JASA NON } \\
\text { KEUANGAN }\end{array}$ & PERSEWAAN & \multicolumn{2}{|c|}{ PERDAGANGAN } \\
\hline Simpan Pinjam & Pasar Desa & Alat Pesta & Perdag.Umum & Ritel Desa \\
\hline SPP & Pamsimas & Gedung & Material & Hasil Tani \\
\hline LKM & Biro Jasa & Alat Pertanian & Tabung Gas & Paving \\
\hline UED-SP & $\begin{array}{ll}\text { jasa } & \text { Rekening } \\
\text { Listrik } & \end{array}$ & Tanah/Kios Desa & Waralaba & Batik \\
\hline \multirow[t]{5}{*}{ UEP } & Jasa Sampah & Ruko \& Kios & Toko hantaran & Sembako \\
\hline & PPOB & Tratag & Toko Pertanian & Hasil Bumi \\
\hline & Jasa Perantara & Alat berat (molen) & Toko Konveksi & Saprodi \\
\hline & Warnet & & Pengasapan Ikan & \\
\hline & Fotocopy & & Terasi dan Abon & \\
\hline PERTANIAN & PETERNAKAN & PERIKANAN & KERAJINAN & WISATA \\
\hline Saprotan & Ternak Ayam & Ternak Ikan & Produk tas \& & Desa \\
\hline
\end{tabular}




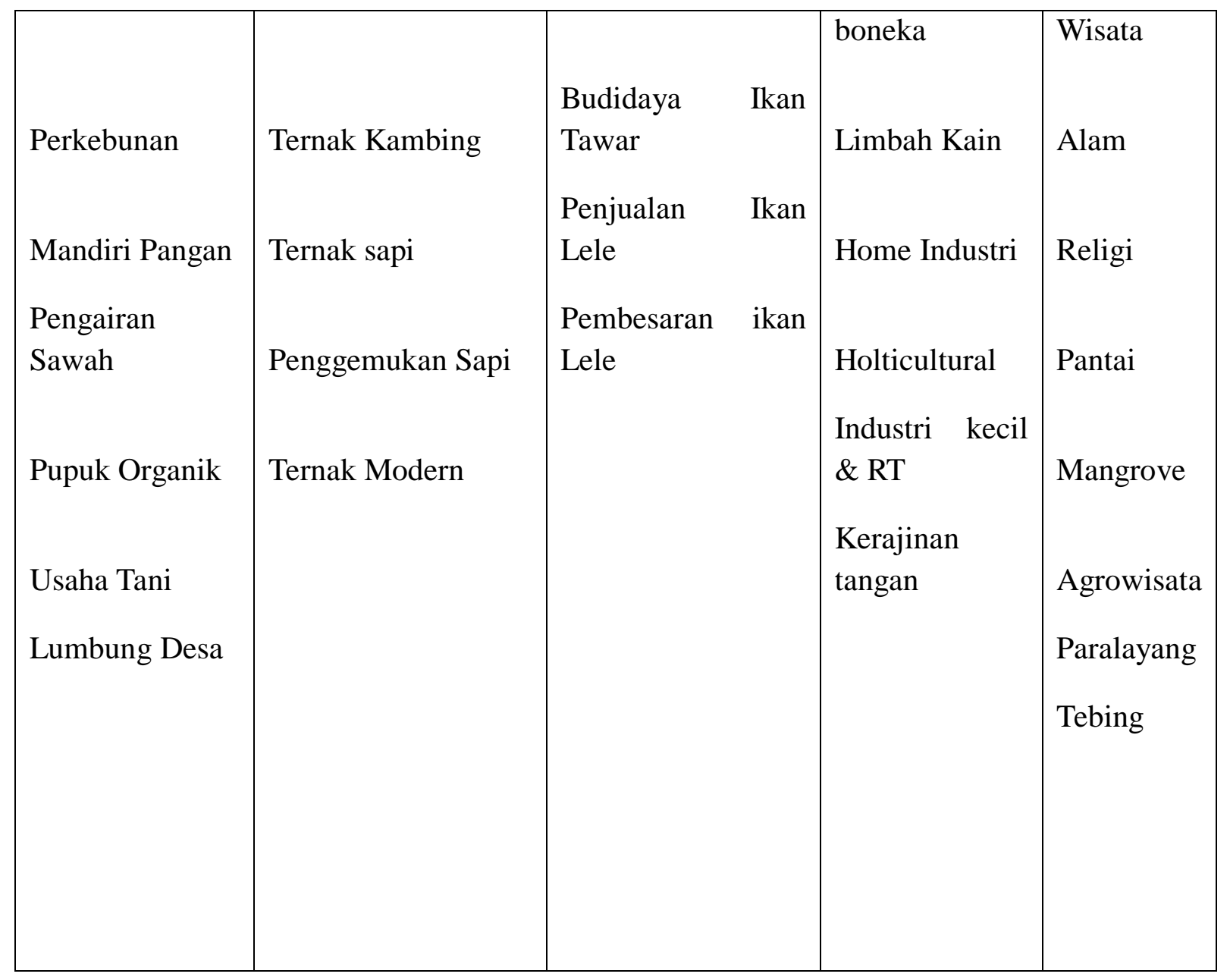

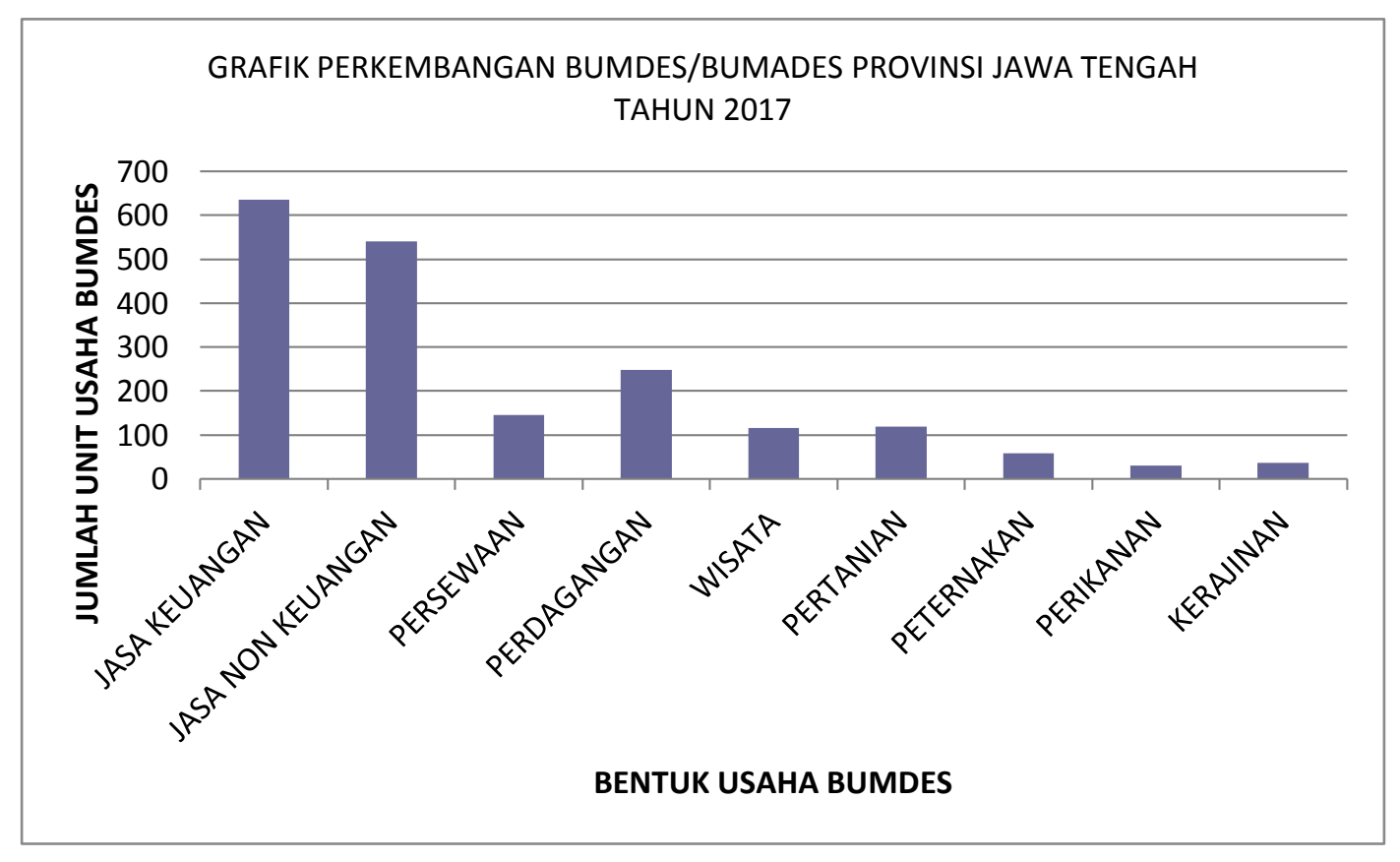

(Sumber data KPW 4 Jateng, 2017) 
Dalam realita dilapangan menunjukkan ada beberapa Pemerintahan Desa yang membentuk BUMDes yang saat sekarang sudah mampu mandiri. Adapun indikatornya dapat dilihat sebagai berikut : (Sumber data KPW 4 Jateng, 2017)

\section{a) Potensi Ekonomi}

Salah satu potensi di Desa Sidowayah dan Desa Ponggok kecamatan Polanharjo Klaten menunjukkan adanya Kehidupan masyarakat yang menggantungkan diri pada sektor pertanian. Lahan pertanian pada umumnya dimanfaatkan untuk persawahan dan hutan rakyat, serta lahan pertanian kering. Keberadaan sumber mata air di kedua desa tersebut ditangkap sebagai potensi alam yang memiliki nilai ekonomi lebih tinggi dibandingkan jika hanya untuk pengairan area persawahan.

Masyarakat Desa Sidowayah tidak ingin menyia-nyiakan keberadaan sumber air semata untuk pertanian. Mereka bersepakat membangun wahana wisata air dengan menduplikasi Bumdesa wisata Air Ponggok yang sudah menasional itu. Di Sidowayah sumber air juga menjadi area pertemuan aktivitas masyarakat, karena pengelola menyediakan kios-kios untuk berjualan, serta area tertutup untuk mandi dan mencuci masyarakat di sekitar Sidowayah.

Selain menjadi ruang transaksi ekonomi masyarakat desa, BUM Desa Sidowayah berpotensi menyumbang desa dalam bentuk Pendapatan Asli Desa, dimana keuntungan bersih BUM Desa dialokasikan untuk pemasukan Desa. Keberadaan BUM Desa memungkinkan perputaran uang terjadi di desa yang kemanfaatannya akan dirasakan untuk seluruh elemen masyarakat. Hal yang sama juga ditemukan di Desa Ngawen Kecamatan Muntilan Kabupaten Magelang, yang mengelola BUMDes wisata tubing.

\section{b) Potensi Sosial}

BUMDes yang menaungi beberapa unit usaha desa memungkinkan terbukanya lapangan kerja bagi masyarakat usia produktif. Sebagian masyarakat terserap menjadi tenaga kerja di rumah sendiri tanpa harus urbanisasi, sekaligus mengurangi angka pengangguran. Selain masyarakat dapat mengakses lapangan kerja di BUM Desa, kelompok ekonomi produktif akan mendapat ruang baru untuk memasarkan produknya melalui kios-kios di sekitar lokasi BUMDes desa Sidowayah, Desa Ponggok dan Ngawen (Kecamatan Muntilan Kabupaten Magelang) yang telah memiliki BUMDes "SEHATI" yang bergerak di sektor wisata (tubing, desa wisata dll). 
Tidak berhenti pada penyediaan peluang kerja bagi masyarakat. BUMDesa pun melakukan beberapa kegiatan sosial. Keberadaan BUM Desa menunjukkan jika secara internal masyarakat memiliki dorongan perubahan yang cepat dalam kehidupan bermasyarakat, menumbuhkan kesadaran kolektif untuk memperbaiki kualitas hidup, dan mencari peluang yang dapat dimanfaatkan untuk kesejahteraan. Hal ini terbangun oleh adanya rasa saling mempercayai, kohesivitas, tindakan proaktif, dan hubungan internal-eksternal dalam membangun jaringan sosial didukung oleh semangat kebajikan untuk saling menguntungkan sebagai refleksi kekuatan masyarakat.

\section{c) Potensi SDM}

Melalui BUM Desa, partisipasi masyarakat menjadi modal sosial yang mampu memperkuat potensi-potensi desa. Modal sosial desa Sidowayah, Desa Ponggok dan Ngawen dapat disaksikan dari proses interaksi antar masyarakat maupun masyarakat dengan pemerintah desa, yang melahirkan ikatan emosional berupa kepercayaan, hubungan-hubungan timbal balik, jaringan-jaringan sosial, nilai-nilai dan normanorma yang membentuk struktur tersendiri yang dipercaya oleh masyarakat kedua desa tersebut. BUM Desa dapat menjadi faktor pendorong terbentuknya kelompok-kelompok minat dalam masyarakat (kelompok pertanian, kelompok lingkungan hidup, kelompok ekonomi produktif).

Beberapa permasalahan umum yang dijumpai di BUM Desa antara lain:
a. Komunikasi
b. Pemberdayaan Masyarakat Lokal
c. Kapasitas manajerial
d. Infrastruktur BUM Desa
e. Transparansi dan akuntabilitas laporan pertanggungjawaban

Dari kelima permasalahan tersebut, dapat disarikan menjadi dua permasalahan utama yaitu mengenai relasi pengurus BUMDesa dengan Pemerintah Desa, dan aspek profesionalitas dalam pengelolaan BUMDesa. Hal ini perlu disadari jika BUMDesa dan Pemerintah Desa memiliki relasi yang erat, karena Pemerintah Desa menjadi pengawas dari kegiatan yang dilakukan BUMDesa. Dalam pengambilan keputusan, BUM Desa menggunakan mekanisme musyawarah dan Pemerintah Desa adalah pemangku kepentingan utama yang terlibat dalam musyawarah tersebut. Hal yang menjadi tantangan bagi BUMDesa dan Pemerintah Desa adalah menjaga keseimbangan relasi, dimana dominasi 
satu pihak terhadap pihak lainnya patut dihindari. Profesionalisme dalam mengelola BUM Desa mengemuka di desa Sidowayah dan Desa Ponggok.

Sedangkan jika menilik landasannya, BUMDesa berdiri karena kohesivitas sosial masyarakat desa dengan seluruh kesukarelaan untuk memajukan desa. Kedua hal ini akan memunculkan dilema pada tata kelola BUM Desa dimana BUMDes dituntut bekerja profesional, di sisi lain harus mengakomodasi tuntutan penyerapan tenaga kerja lokal, dimana SDM lokal memiliki kapasitas dan kapabilitas yang terbatas. Sedangkan dari sisi sosial, keberadaan BUMDes membawa perubahan yang signifikan. Perubahan tersebut tampak dari bergesernya semangat volunterisme menjadi transaksional. Pergeseran dari pekerjaan yang bersifat sukarela dan gotong royong menjadi pekerjaan yang mengharapkan adanya upah.

Di satu sisi, BUMDesa yang merupakan sebuah badan usaha yang dibentuk oleh masyarakat desa berdasar asas gotong royong dan keterbukaan. BUM Desa dituntut agar melayani kebutuhan seluruh masyarakat, membuka akses yang luas bagi keterlibatan masyarakat dalam pengelolaan dan pengawasan. Sedangkan di sisi yang lain ada desakan dari masyarakat agar BUM Desa dikelola secara profesional agar mendatangkan keuntungan yang besar dan pengelolaan yang transparan.

Keadaan tersebut memaksa BUMDesa dikelola secara tangkas (ambidextrous). Secara teoritik Robert Duncan (1976), menyebutkan jika sebuah organisasi dihadapkan pada keadaan yang saling bertentangan pada saat bersamaan, pengelola organisasi harus memiliki ketangkasan dalam mengakomodasi keberpihakan yang saling bertentangan. Maka pengelola BUMDesa harus lebih terbuka dalam mengembangkan pola pengelolaan yang bersifat sosial dan profesional dalam waktu yang bersamaan. BUM Desa memiliki kondisi yang berbeda yang dipengaruhi oleh latar belakang pendirian dan karakter masyarakat. Sebagai organisasi yang tumbuh dan berkembang dalam kehidupan sosial masyarakat desa. BUMDesa perlu mengembangkan dialog bersama masyarakat untuk mendapatkan gambaran tentang pengelolaan organisasi BUM Desa yang profesional versi masyarakat. Hal ini dapat pula mereduksi kesan yang terbentuk bahwa ada unsur keberpihakan yang kuat antara pengurus dan pengelola BUM Desa dengan Pemerintah Desa.

Keberlanjutan (sustainability) BUM Desa sangat bergantung pada kemampuan pengelolaan organisasi, karena BUM Desa berada dalam situasi yang membutuhkan 
ambidextrous management untuk menjadi organisasi bisnis sosial. Jika aspek sosial menjadi titik berat BUM Desa, maka perlu disadari jika prinsip gotong royong dan kesukarelaan (volunteerism) membutuhkan komitmen yang kuat untuk mengikat pihak-pihak yang mengelola BUM Desa. Sedangkan jika BUM Desa akan diarahkan menjadi organisasi bisnis profesional, mengakibatkan pola relasi yang transaksional dan rendahnya rasa memiliki (sense of belonging) pada modal sosial yang membentuk BUM Desa.

Misi pengembangan BUM Desa adalah menggerakkan roda ekonomi desa dengan mengoptimalkan potensi desa. Jika desa mampu mengoptimalkan seluruh potensi sumber dayanya untuk menggerakkan perekonomian dan menyediakan lapangan kerja bagi masyarakat usia produktif, maka pengembangan dan penguatan BUM Desa diharapkan mampu mengurangi angka pengangguran dan urbanisasi. Desa bersama seluruh elemennya, perlu memiliki komitmen untuk mengembangkan unit usaha dan inovasi yang menjadi potensi baru di desa agar misi BUM Desa terwujud, sebagai penggerak kehidupan desa.

Maka sebaiknya untuk ke depan diambil langkah-angkah sebagai berikut

a) Pengurus BUMDes, Pemerintah Desa, masyarakat, lembaga lain yang hendak melakukan pendampingan, dan/atau perusahaan yang akan melakukan investasi di desa, secara bersama-sama perlu melakukan analisis rantai distribusi. Hal ini bertujuan agar pengelolaan ekonomi perdesaan terkelola dari hulu ke hilir. Jika rantai distribusi teridentifikasi maka roda perekonomian desa akan bergerak secara selaras dan secara simultan dapat mengembangkan Desa Wirausaha.

b) Pemerintah desa bersama pengurus BUM Desa, masyarakat, dan pihak eksternal mengkaji secara komprehensif potensi desa (sumber daya alam, sumber daya manusia, dan sumber daya buatan) untuk membuka ruang terciptanya unit-unit usaha baru yang memungkinkan terciptanya lapangan kerja yang semakin besar dan terbuka bagi kelompok masyarakat marjinal.

c) Pemerintah desa mampu menginisiasi dan mendorong masyarakat, pengurus BUMDes, untuk menciptakan keunggulan kompetitif desa, sehingga tercipta one village one product. Penciptaan keunggulan kompetitif dari tiga desa model harus berdasar pada (i) diferensiasi hasil produksi; (ii) biaya produksi rendah (low cost); dan (iii) respons cepat pada perubahan dan kebutuhan inovasi.

\section{H. PENUTUP}




\section{a. Kesimpulan}

1. Melihat kondisi desa yang ada sekarang secara nasional diperlukan langkah-langkah khusus dalam rangka implementasi UU Desa. Adapun langkah-langkah paralel yang harus diperhatikan dan dilakukan dalam rangka mensukseskan implementasi UU Desa antara lain adalah : Pertama, tingkat kesiapan Perangkat Desa dan Kelembagaan Desa (kuantitas dan kualitas). Secara kuantitas sebagian besar desa saat ini tidak memiliki perangkat yang lengkap sebagaimana diatur dalam PP 43 /2014 pasal 61-pasal 64. Sementara itu perangkat yang tersedia kapasitasnya masih perlu ditingkatkan. Kedua, kualitas penyususunan dokumen Perencanaan Pembangunan Desa (RPJM Desa, RKP Desa dan APB Desa). Berdasarkan PP 43 /2014 psl 114-115 dan PP 60 /2014 ps1 20 disebutkan penggunaan Dana Desa mengacu pada Rencana Jangka Menengah Desa (RKPDes) dan Rencana Kerja Pemerintah Desa (RKPDes).

2. Terkait pengelolaan keuangan desa memang diperlukan kapasitas pemerintahan desa yang menguasai teknis dan mekanisme mengelola keuangan yang terlatih dan profesinal. Dengan sejumlah persoalan yang ada saat sekarang menjadikan umpan balik dalam upaya perbaikan kapasitas pengelolaan keuangan desa bersama-sama semua pemangku kepentingan (stakeholders), pelaku dilapangan, kelompok peduli/ relawan dan semua masyarakat desa, kaena dana desa haruslah mampu memajukan desa dan mensejahterakan masyarakat desa. Untuk memperjelas batasan korupsi dana desa, Kemendagri, Kemendesa PDTT, Kemenkeu, BPKP, kepolisian, kejaksaan, dan KPK bersama-sama mengharmoniskan aturan korupsi desa. Setidaknya terkait hal-hal sebagai berikut: indikator dan jenis korupsi desa, tata cara pelaporan dan perlindungan saksi, proses pencegahan dan pembuktian korupsi, dan sanksi.

3. Dalam kapasitasnya peran pemerintahan desa dalam pengembangan BUMDesa adalah menggerakkan roda ekonomi desa dengan mengoptimalkan potensi desa. Jika desa mampu mengoptimalkan seluruh potensi sumber dayanya untuk menggerakkan perekonomian dan menyediakan lapangan kerja bagi masyarakat usia produktif, maka pengembangan dan penguatan BUMDesa diharapkan mampu mengurangi angka pengangguran dan urbanisasi desa ke kota.

\section{b. Saran}


Adapun hal-hal yang terkait implementasi UU Desa tentang pengelolaan keuangan desa yang perlu diperhatikan adalah dalam rangka peningkatan kapasitas pemerintahan desa dalam mengelolanya secara optimal yaitu antara lain :

1. Menetapkan standar minimum pelayanan yang berlaku seluruh daerah dalam penetapan penyusunan APBDes disetiap desa.

2. Pemerintah pusat harus berpendirian pada prinsip mempermudah penyaluran maupun pencairan dana desa dengan konsistensi dalam penerapan peraturan pemerintah sehingga tidak menyulitkan pemerintah daerah maupun pemerintah desa dalam memenuhi persyaratan-persyaratan yang ditetapkan.

3. Melalukan pendampingan kepada desa yang masih memiliki potensi yang belum mampu melakukan penyusunan APBDes dengan baik dan benar. Pendampingan tersebut dapat dilakukan oleh elemen pemerintah baik pemerintah pusat maupun pemeintah daerah dan perguruan tinggi serta NGO yang capable.

4. Laporan pengelolaan harus sederhana agar dapat dimengerti oleh para perangkat desa namun tetap memenuhi prinsip transparansi dan akuntabilitas.

5. Proses penyusunannya perlu dilakukan secara partisipatif dengan memberikan ruang kepada seluruh pemangku kepentingan untuk memberikan masukan.

6. Badan Permusyawaratan Desa (BPD) yang berisi wakil masyarakat desa harus berperan aktif melakukan pengawasan dan mendorong masyarakat untuk ikut mengawasi pengelolaan dana desa.

7. Tentang BUM Des : Pemerintah desa mampu menginisiasi dan mendorong masyarakat, pengurus BUMDes, untuk menciptakan keunggulan kompetitif desa, sehingga tercipta one village one product. Penciptaan keunggulan kompetitif dari tiga desa model harus berdasar pada (i) diferensiasi hasil produksi; (ii) biaya produksi rendah (low cost); dan (iii) respons cepat pada perubahan dan kebutuhan inovasi.

\section{DAFTAR PUSTAKA}

Ali Mufiz, Drs. MPA, Pengantar Administrasi Negara, Karunika Jakarta , Uiversitas Terbuka 1985

Arie Sulandro, Bahan Paparan Pemetaan Good Governance, Peningkatan Pelayanan Pulik dan Penanggulangan KKN di Propinsi Kepulauan , BPKP Pusat Jakarta-www.kepriprov.go.id, 14 November 2006. 
Fandy Tjiptono, Manajemen jasa, Andi Offset, Yogyakarta, 1996.

Guy Beneviste, Birokrasi, Rajawali Pers, Jakarta, 1994

H.Dadang Solihin Drs., MA, Makalah Lokakarya Model Indeks Pemerintahan Indikator Governance dan Penerapannya dalam Mewujudkan Demokratisasi di Indonesia, Bappeda Jawa Barat Bandung, 17 April 2007.

Hessel Nogi S.Tangkilisan, Drs. M.Si, Kebijakan Publik yang Membumi, Lukman Offset YPAPI, Yogyakarta, 2003.

Koenjaraningrat, Metode-metode Penelitia Masyarakat, Gramedia, Jakarta, 1980.

Moeloeng, Lexi J.(2008), Metodologi Penelitian Kualitatif, Bandung: PT Rosdakarya

Nawawi, ,Hadari (1994), Metode Penelitian Ilmiah, Jakarta:Rineka Cipta

Pariara Westra,Drs,SH, Ensiklopedia Administrasi, Gunung Agung, Jakarta, 1981.

Solichin Abdul Wahab, Drs, MA, Analisis Kebijakan Dari Formulasi Ke Implementasi Kebijaksanaan Negara, Bumi Aksara,Jakarta, 1991

Suharsimi Arikunto Dr.. Prosedur Penelitian, Suatu Pendekatan Praktek edisi revisi V. Jakarta , November 2002.

Suharto Edi, Makalah Pembangunan Kesejahteraan Sosial dalam Pusaran Desentralisasi dan Good Governance, Balai Besar Pendidikan dan Pelatihan Kesejahteraan Sosial (BBPPKS) Banjarmasin, 21 Maret 2006.

Sondang P.Siagian, Prof,Dr, Filsafat Administrasi, Gunung Agung ,Jakarta, 1995

The Liang Gie, Keadilan sebagai Landasan bagi Administrasi Pemerintahan dalam Negara Republik Indonesia, Liberty, Yogyakarta, 1993.

Wayne Parson, Public Policy, Pengantar Teori dan Praktek Analisis Kebijakan, Kencana Prenada Media Group,Jakarta, 2006

Undang-Undang RI Nomer 6 Tahun 2014 tentang Desa

PP Nomor 43 Tahun 2014 tentang Peraturan Pelaksanaan UU Nomor 6 Tahun 2014

PP Nomor 60 Tahun 2014 tentang Dana Desa yang bersumber dari APBN

Permendagri No. 113 Tahun 2014 tentang Pengelolaan Keuangan Desa

Permendagri No. 114 Tahun 2015 tentang Pembangunan Desa; 
PERMENDESA Nomer 5 Tahun 2015 tentang Penggunaan Dana

Sumber data KPW 4 Provinsi Jateng, 2017 